Conceptualizing Interactive Network Branding in business markets: Developing roles and positions of firms in business networks

\begin{tabular}{|r|l|}
\hline Journal: & Journal of Business and Industrial Marketing \\
\hline Manuscript ID & JBIM-11-2018-0332.R3 \\
\hline Manuscript Type: & Original Article \\
\hline Keywords: & $\begin{array}{l}\text { Interactive Network Branding, business networks, Interaction, role and } \\
\text { position, corporate branding }\end{array}$ \\
\hline \multicolumn{2}{l}{} \\
\end{tabular}

SCHOLARONE
Manuscripts 


\title{
Conceptualizing Interactive Network Branding in business markets: Developing roles and positions of firms in business networks
}

\begin{abstract}
Purpose - The paper presents the concept of Interactive Network Branding (INB) in business markets. The INB conceptualization offers an understanding of corporate branding processes as an inherent part of business networking. More specifically, the paper focuses on the importance of INB for firms that are developing their roles and positions in business networks.
\end{abstract}

Design/methodology/approach - The conceptual paper reviews the extant literature on corporate branding in conjunction with business network research. This perspective adds to the current knowledge of business marketing by proposing a theoretical framework of INB.

Findings - The conceptualization of INB offers a specific network lens on corporate branding by presenting three INB dimensions. The first dimension deals with corporate identity; the second with corporate reputation; while the third, mutual INB dimension, presents an 'interactive space' where branding and networking collide. These three dimensions are enacted by individuals acting on behalf of their companies, as key implementers of INB processes. Through the INB, strategic roles and positions of firms embedded in their business networks are formed.

Research implications/limitations - The paper contributes to current literature on business network research that has left a corporate brand perspective almost unnoticed. The INB concept also offers an extension to current literature on corporate branding, which has to date neglected business relationships and networking issues. Being strongly conceptual, the paper notes that empirical research is needed for observing the role of INB in real-life business encounters.

Practical implications - The article provides novel ideas and implications for firm representatives responsible for branding and relationship development in business networks. It denotes the critical role of individuals and their interactions with other individuals, which influences the development of specific network roles and positions for connected business entities.

Originality/value - The used multidisciplinary approach provides a conceptual platform to study branding processes in business networks. By offering a network perspective to corporate branding, new and relevant implications for both theory and practice are forefronted.

Keywords: Interactive Network Branding, business networks, corporate branding, interaction, role and position.

Article classification: Conceptual paper 


\section{Introduction}

A significant amount of marketing research has been conducted in the field of corporate branding in recent years. Branding research has focused firmly on consumer markets and defined corporate branding as the practice of communicating brands to end customers through the name, symbol, sign, or logo of a company (Aaker, 1996; Webster and Keller, 2004). However, some practitioners and researchers have also realized the importance of branding in business-to-business (B2B) markets by focusing on communicating brands to business customers and other business actors (Balmer and Gray, 2003; Mudambi, 2002; Seyedghorban et al., 2016). This perspective has provoked the following thinking: "corporate brands represent one of the most fascinating phenomena of the business environment in the twentyfirst century" (Balmer and Gray, 2003, p. 972).

Corporate branding is described as the activity of a company that is focused on creating specific perceived business value in the mindsets of firm's key business counterparts (Schultz and de Chernatony, 2002; Bengtsson and Servais, 2005). Despite the noted importance and benefits of corporate branding, some apparent gaps exist concerning how it should be dealt with in B2B marketing and implemented in practice (see e.g., Melewar et al., 2012; Purchase et al., 2015; Seyedghorban et al., 2016). For instance, corporate branding has traditionally been considered as a responsibility of a single firm, with little or no dialogue with other actors within a business network (Mäläskä et al., 2011). In line with these concerns, a first research gap in the paper is concerned with a lack of an explicit network perspective on corporate branding in business marketing research.

When examining business network research, a clear strand of literature focuses on relational interdependencies between business partners that develop long-term relationships (Håkansson, 1982; Håkansson and Snehota, 1995; Ford, 2004; Håkansson et al., 2009). Through business interaction, these actors influence the roles and positions of each company embedded in sets of connected business relationships (Johanson and Mattsson, 1992; Brennan and Turnbull, 2002). However, developing specific roles and network positions of companies are indubitably influenced by corporate branding activities, where other connected actors in business networks are involved. Thus, it can be noted that a clear branding perspective to the study of business networks is at its very early stages, and not well elaborated conceptually or empirically (see arguments by, e.g., Mäläskä et al., 2011; Koporcic and Halinen, 2018). Scrutinizing the importance of corporate branding in business networks presents a second research gap to be tackled in this paper. In order to bridge these two gaps, we cross-fertilize ideas between two different research fields.

This paper thus elaborates further and theorize the Interactive Network Branding (INB) concept, with a focus on how firms act and develop their roles and positions in business networks. The INB perspective on branding highlights the role of business interactions and mutual interdependencies between firms embedded in networks (Koporcic and Törnroos, 2015; Koporcic, 2017; Koporcic and Halinen, 2018). Besides being focused on business networks, as a critical constituent of business markets (Håkansson, 1987; Håkansson and Snehota, 1995; Turnbull et al., 1996; Håkansson et al., 2009), INB emphasizes the 
importance of individual human actors dealing jointly with both branding and networking processes (Koporcic and Halinen, 2018). Involved firm representatives act on behalf of their firms and interact with representatives of other firms acting with a similar mandate. In this sense, firms and individuals become intertwined in both networking and branding processes. Building on this currently emerging research perspective, we contribute to existing research in both corporate branding and business networks. By applying a multidisciplinary approach, we take notice of the argument made by Schultz and Hatch $(2005$, p. 341) that "no discipline alone provides the full spectrum of knowledge needed for successful corporate brand management."

The paper is divided into three parts. First, the extant literature on corporate branding and business networks is reviewed. The former focuses on business marketing and organizational research on corporate branding. The next section deals with the relevance and conceptual development of INB in close conjunction with the strategic concepts of position and role of companies embedded in business networks. This section also presents key dimensions of INB and discusses them in more detail. After that, a conceptual model of INB is presented. The final section concludes the paper together with conceptual, methodological, and managerial implications and issues for future inquiry.

\section{Literature review}

Following the development of the two streams of literature mentioned above, a variety of perspectives related to the concept of INB are examined. Thus, the literature review focuses on the presented gaps found in the corporate branding and business network literature.

\subsection{An overview of corporate branding literature}

Knowledge on corporate branding has been expanding rapidly after King's (1991) seminal article on "Brand building in the 1990s", and shows no signs of decreasing (see, e.g., review of Fetscherin and Usunier, 2012; Melewar et al., 2012; Seyedghorban et al., 2016). However, despite a growing interest in corporate brands, its complex nature seems to be an issue to note. This is especially noted regarding various theoretical and practical demands and expectations that corporate brand research is facing (Gyrd-Jones et al., 2013; Koporcic et al., 2018).

The complex nature of corporate branding is seen in its key terminology, influenced by its multidisciplinary nature (Knox and Bickerton, 2003; Balmer, 2017). Other issues deal with the broad scope of application to different areas (Gyrd-Jones et al., 2013), and a need for involvement of multiple actors with different needs and requirements (Schultz and Hatch, 2003; Biraghi and Gambetti, 2015). Research within business marketing, management, economics, organizational behavior, design, graphic arts, strategy, and sociology have proposed a multitude of different concepts and conceptual frameworks concerning branding (cf. Mukherjee and Balmer, 2008). As Ind (1997, p. 2) has noted: "Corporate branding is one of those things that everyone believes is important, yet there is very little consensus as to what 
it means." Although this statement was written two decades ago, it still seems relevant.

Initially, in the early 1990s, corporate brands were mainly conceptualized through their visual and graphic design (Aaker, 1991). The use of symbols, the logo of a company, and colors played an essential role in building a corporate brand and communicating in business markets (Simões et al., 2005). However, researchers have broadened their perspectives in recent years, and corporate branding research has started to combine different approaches and research avenues to gain a better understanding of the subject. As a result, corporate branding is being recognized as a process of building a desired reputation of a firm in its markets (e.g., Abratt and Kleyn, 2012; Walker, 2010; Koporcic and Halinen, 2018), while continually maintaining and developing its identity (e.g., Brown et al., 2010; Giotsi and Wilson, 2001; Koporcic and Halinen, 2018). This specific use of key terminology is also forming a starting point of this conceptual paper. Since the concepts related to corporate branding have different disciplinary roots, we are dealing next with both inter-organizational and business marketing literature concerning corporate branding.

\subsubsection{Organizational research on corporate branding}

Organizational research on corporate branding focuses on and analyzes the organizational settings of a company, how it is organized, and what meaning branding brings to a company (Aaker and Joachimsthaler, 2000; Aaker, 1996; Schultz and Hatch, 2005, 2007). Consequently, the organizational perspective is associated with the internal facet of corporate brands, which denotes the importance of identity that is built within the firm (Hatch and Schultz, 2009). Corporate identity can thus be described as "an inside view on the company, denoting how employees internally perceive their company and how they aim to present it to the outside world" (Koporcic and Halinen, 2018, p. 395).

The importance of corporate brands in organizational studies has also been studied longitudinally by analyzing a company's existence over time, i.e., how it has developed in the past, how it exists in the present, and in relation to its potential future state (Schultz and Hatch, 2003). This notion of time and process is an essential factor for every corporation and has practical relevance and value for understanding how corporate branding is managed and developed internally in firms over time. As Simões et al. (2005, p. 155) state: "In creating an identity, organizations internalize a cognitive structure of what they stand for and where they intend to go." By extension, this acknowledges the importance of individuals representing organizations and influencing corporate identities and corporate branding in general (Albert $e t$ al., 2000; Hatch and Schultz, 1997; Koporcic and Halinen, 2018). However, organizational studies have often sidestepped, or only implicitly acknowledged the importance of the external environment surrounding a company, i.e., the importance of relevant business actors in the firms' close network relationships. We acknowledge, however, that the stakeholder perspective on corporate branding represents a similar type of understanding, by providing a spectrum of knowledge by offering an external perspective of the firm. We turn closer to this issue in the next section.

\subsubsection{Business marketing research on corporate branding}


Business marketing literature offers a relational view of corporate branding by stressing the importance of other business actors surrounding a company in B2B markets. These actors are directly having an impact on how a company will be perceived in its connected business network. This perception corresponds well with the concept of corporate reputation that is created externally on the market, by a firm's current and potential partners (see, e.g., Abratt and Kleyn, 2012; Koporcic and Halinen, 2018). However, business marketing research offers to date a limited number of contributions that deal with the topic of corporate branding (Brown et al., 2010; Seyedghorban et al., 2016). To illustrate this issue, the literature review by Herbst, Schmidt, Ploder, and Austen (2012), concerning B2B branding-related ${ }^{1}$ articles $^{2}$ published in the period of twenty-four years up to 2011, provides an overview of the status quo of $\mathrm{B} 2 \mathrm{~B}$ branding research. Based on their quantitative analysis, the results show that Journal of Business Research (JBR) published only 6 brand-related articles out of 2436 articles; the Industrial Marketing Management (IMM) Journal published 43 out of 1602; Journal of Business and Industrial Marketing (JBIM) 17 out of 817; Journal of Business-toBusiness marketing (JBBM) 4 out of 188 articles; Journal of Product and Brand Management (JPBM) 13 out of 722 .

Moreover, up to 2008, the IMM Journal, in its thirty-seventh year as a leading journal in the field, had published only four articles related to corporate identity and reputation, as essential aspects of B2B and corporate branding research (Brown et al., 2010). Plausible reasons for this overlooked area of research is analyzed by Seyedghorban et al. (2016, p. 12) in their "trajectory of B2B branding research" as follows:

1) Branding was considered mainly irrelevant to marketing scholars before 1991. Thus, there was limited empirical research on this subject in business marketing studies;

2) 1992-2006: more importance was attached to branding for industrial companies, resulting in only a small amount of research focused on the benefits of branding;

3) 2007 to the present day: more research has been conducted, but it has mostly focused on the role of brand equity as a strategic company resource, while other elements are still left aside.

Despite the strengths of theoretical perspectives in corporate branding research, it can thus be concluded that relevant definitions, theoretical frameworks, and a clear understanding of the role of corporate branding requires further research. Roper and Davies (2007) also noted this problem by questioning whether the creation of corporate brands is managed inside an organization, externally, or in cooperation between relevant actors (see also Vallaster and Lindgreen, 2011; Törmälä and Gyrd-Jones, 2017; Koporcic and Halinen, 2018). Following this line of reasoning, we propose a perspective that aims to narrow the aforementioned gaps in corporate branding literature by noting the crucial role of business interactions, relationships, and networks. Despite the potential difficulties involved in formulating a link between the two chosen research fields, it is worth mentioning that a relational view is a central constituent in both corporate branding and business network research (Mäläskä et al., 2011; Koporcic and Halinen, 2018).

\footnotetext{
${ }^{1} \mathrm{~B} 2 \mathrm{~B}$ branding consists of both corporate and product branding.
} 
A business network is defined as a set of interactive relationships in business markets (Håkansson et al., 2009). The business network forms a critical arena for connected firms in networks, which replaces a classical atomistic large-scale markets approach. Thus, when we refer to business network research, we focus on B2B marketing inquiry dealing explicitly with embedded business relationships and relational exchanges in business settings (Anderson et al., 1994; Håkansson, 1982; Håkansson and Snehota, 1995; Håkansson et al., 2009). This interactive network approach (i.e., the IMP perspective) presents the interplay between actors, activities, and resources in business markets (Håkansson and Snehota, 1995). The IMP approach presents a leading perspective in current business marketing research (Möller, 2013).

However, the importance of corporate branding has been so far only emerging as a new perspective in business network research. However, some notions related to branding can be, at least implicitly, traced in earlier work of the IMP Group. For instance, Anderson, Håkansson, and Johanson $(1994$, p. 4) put forth that: "Network identity is meant to capture the perceived attractiveness of a firm as an exchange partner. [...] It refers to how firms see themselves in the network and how they are seen by other network actors." This view relates to and embodies elements of an internally created corporate identity in relation to an externally created reputation that characterizes how a company is viewed by its business counterparts at a certain point in time. In this manner, corporate branding (especially its two central elements: identity and reputation) brings relevance to a company by influencing its future networking goals. This view presents a relevant overlap between branding and network research, providing a foundation for further contributions.

A corporate branding viewpoint can be found in a limited number of studies with similar connotations. Studies conducted by Bengtsson and Servais (2005) and Kalafatis et al. (2012) present examples of co-branding activities in industrial markets. Co-branding is defined as cooperation between companies, in which two or more branded products enter the marketplace together. The example of co-branding in consumer markets is presented by the campaign "Apple Pay", in which MasterCard started to collaborate with Apple. In industrial markets, examples presented by Kalafatis et al. (2012) are the following: Sony Ericsson and Carphone Warehouse, Royal Mail Group and the Barnardos children's charity, and Flash with Febreze. These examples have shown the importance of collaborations for the reputation endorsement of both involved partners. And although Bengtsson and Servais (2005) focused only on product branding, they refer to Mudambi, Doyle, and Wong (1997) and their argument on the importance of business relationships with "well-known" suppliers, denoting the importance of corporate reputation. When suppliers have a positive reputation on the market, it can induce trust and reduce the perceived risk of choosing a potential business partner. Similar ideas are presented in Jalkala's and Salminen's (2010) study on the use of references by suppliers in business markets. Also, the study by Mäläskä et al. (2011) describes the importance of collaboration between business partners in small and mediumsized enterprises (SMEs) branding activities. Finally, Urde and Greyser (2015) propose an understanding of heritage brands in networks, focusing on both the identity and reputation of 
brands. Their "brand-oriented network" concept attempts to describe a network of brands as a phenomenon that can be used for building alliances, such as co-branding undertakings, or similar type of joint ventures. Despite these reviewed studies, in which branding in B2B markets has been recognized, well-grounded network-orientated models and theoretical constructs need much more attention.

Based on these reviews, we can summarize that branding is a promising area for further inquiry related explicitly to business networking. Next, we aim to combine the fundamental tenets and viewpoints of this review by presenting and modeling the concept of Interactive Network Branding (INB) that offers a network perspective on corporate branding.

\section{Conceptual development of Interactive Network Branding}

In this section, we elaborate on how the IMP network approach and corporate branding perspectives can be closer aligned by presenting key strategic constructs of the INB concept. Although the INB presents both strategically planned and organically emerging branding activities (see Koporcic and Halinen, 2018), we focus here on its strategic orientation. Thus, according to the perspective taken here, INB presents strategic actions of companies that are aiming to achieve desired network positions and roles by creating a strong corporate identity and reputation in the mindsets of key actors in business settings (Koporcic, 2017; Koporcic and Halinen, 2018). In order to understand the complexity of the INB, we start by examining the IMP concepts of role and position, denoting both strategic and dynamic characteristics of actors embedded in business networks (Abrahamsen et al., 2012; Anderson et al., 1998; Johanson and Mattsson, 1992; Purchase et al., 2015; Turnbull et al., 1996).

The "role" of an actor in its business network can be defined through the firm's behavior in relation to its business activities (Anderson et al., 1998; Purchase et al., 2015). Some typical networking roles include how companies are performing their activities through their positions, e.g., as a manufacturer, service or materials provider, distributor, assembler, intermediary, or end-user. These roles are socially constructed, since they include business actors' free will to choose what they will do, but are also influenced by other actors' expectations, as well as by needs of a market (Anderson et al., 1998; Purchase et al., 2015; Abrahamsen et al., 2012). As Anderson et al. (1998, p. 172) highlight: "role is a concept for describing what the actors intend, how they construct meaning in their situation and how they want to change it." Acting and performing activities in a specific role, thus relate to how well an actor enacts its capability for potential others and constructs a meaning of its corporate brand in a business network. The role has further bearing on and influences the creation of an actors' specific network position.

Turnbull et al. (1996, p. 47) have defined the position concept as follows: "Network position consists of the company's relationships and the rights and obligations which go with them." The concept of position relates to the importance a firm plays in relation to other actors in a network of interdependent business relationships (Johanson and Mattsson, 1992; Turnbull et al., 1996). Network positions are strategic and changing, dealing with the roles that firms 
employ (Anderson et al., 1998; Johanson and Mattsson, 1992; Turnbull et al., 1996). In the IMP research, a perspective related to branding has been articulated by Håkansson and Snehota (1995, p. 201) by arguing that: "A company's position in the overall web of bonds, whom it is committed with, its existing bonds, affects its identity as well as its character." Over time, actors build and maintain (or change) their positions by acting in their role(s) accordingly (Håkansson, 1987), while at the same time, building and maintaining their corporate brands within embedded networks and beyond.

While the concepts of network position and role are tightly coupled with each other, Abrahamsen et al. (2012) show that a network actor's role - and how it is enacted - is not merely a function of its network position. Instead, it is also partially an actor's strategic choice. Thus, two firms occupying a similar position may choose to act differently. This showcase that the roles and positions of actors in networks both change and affect each other mutually and strategically from a branding perspective. Each connected company will thus have a different interpretation of roles and positions in relation to its business partners. For example, the same firm can be seen as a loyal and close partner to one and distant or difficult partner to another firm (Abrahamsen et al., 2012). In other words, networking activities will influence how each firm is perceived in the connected business market. As such, this has a bearing on branding processes that are unfolding over time through constant interactive exchanges between actors, where corporate identities and reputations are created and developed within a dynamic business network setting. In addition, individual managers (and other firm representatives) play an essential part in these processes (Wider et al., 2018), as the identities and reputations are situated in the mindsets of individuals (Koporcic and Halinen, 2018). These impressions are also disseminated to potential others, mainly through individual interactions, as corporate brands are perceived mental constructs held by human actors. Roles and positions are thus influencing and are influenced by brand impressions that others hold about the firm.

Following these conceptual perspectives, we aim to develop cross-disciplinary solutions that align the proposed concepts more closely and demonstrate their relevance for business actors in dynamic networks. We share the thoughts by organizational theorists Schultz and Hatch (2005, p. 343) as they noted: "If we begin to accept the need for comprehensive, integrated frameworks while opening up to multiple disciplines, more realistic and actionable guidelines are likely to emerge." Adopting this as a guiding principle, we define INB in a three-fold manner, as: (i) a socially constructed interactive business process; (ii) being enacted and mediated through human actors; and (iii) built on the strategic concepts of roles and positions in dynamic business networks. The ongoing interactions between actors denote the processual character of business relationships and the resulting networking effect found in corporate branding research.

To sum up, we denote that both the position and role of connected firms are affected both by their reputation in a network as well as their identity-building processes. Next, we develop these conceptual perspectives further by presenting specific INB dimensions from this viewpoint. 


\subsection{Dimensions of INB}

\subsubsection{Internal branding dimensions}

Starting with the internal dimensions of INB, we turn back to organizational theory (see section 2.1.1). A key concept of this research on branding is the corporate identity (see, e.g., Albert et al., 2000; Gioia et al., 2000; Simões et al., 2005). Corporate identity refers, in organizational research, to internal relationships between individuals and their organization, focusing on human insights and perceptions (e.g., Dutton et al., 1994; Hatch and Schultz, 1997). Consequently, identity describes how individuals perceive their company and what it presents, including how they communicate that message externally (Morgan et al., 2007). Individuals are thus acting as brand champions (Morhart et al., 2009), representing the most significant group regarding the internal aspect of corporate branding (Ind, 1997). These human actors communicate and interact with each other, handle their inter-firm relationships and participate in the production, innovation, and co-creation of products and services (Ind, 1997; Schultz and Hatch, 2003; Harris and de Chernatony, 2001; Medlin and Törnroos, 2007, 2009). As Schultz and Hatch (2005, p. 48) note, "it is human nature to personify things with which we have relationships, and companies rely upon scores of human relationships to stay in business."

Although some recent studies have suggested different models of internal branding (see, e.g., de Chernatony and Cottam, 2008; Morhart et al., 2009; Vallaster and de Chernatony, 2006), they did not fully resolve the challenges of corporate branding. In most firms, a single person does not manage a corporate brand alone. Instead, every individual is a brand ambassador, communicating the corporate brand through its interactions, both inside and outside of the company. In addition, given that companies interact with each other to conduct business, the creation of a specific corporate identity in the mindsets of other actors in a network becomes a significant strategic concern. Some research has already indicated that a purely internal perspective, i.e., the corporate identity of a firm can be affected by changes in the corporate reputation (e.g., de Chernatony and Harris, 2000; Dutton et al., 1994). Other brand researchers argue that the identity of $\mathrm{B} 2 \mathrm{~B}$ firms can change rapidly, in correspondence to demands of a firm's closely connected business partners (Gioia et al., 2010; Scott and Lane, 2000; Törmälä and Gyrd-Jones, 2017). This is especially relevant for new companies in business markets (Kantanen, 2012), and indicates, at least to some extent, a shift from an internal towards an external perspective of a company. It furthermore relates to how a company strategically attempts to position itself within the business network and how it wishes to be perceived by others through the role(s) it plays.

\subsubsection{External branding dimensions}

From a business market perspective (see section 2.1.2), the external branding dimension focuses on corporate reputation. Although corporate reputation has been in the focus of attention for both academics and practitioners (Davies et al., 2003; Urde and Greyser, 2015), its definitions lack clarity, as Walker (2010) demonstrated in his literature review. Only 19 out of 43 of the articles they reviewed offered some kind of a definition of the concept. Following Johnson and Zinkhan (1990), and in line with Abratt and Kleyn (2012), we define 
corporate reputation as an overall impression of how other network actors perceive and value a company. These impressions are created externally in a business network, both by the firm's current and potential business partners (Koporcic and Halinen, 2018; Wider et al., 2018). Consequently, reputation denotes how business actors embedded in a connected business network (and beyond), perceive a focal company and what it represents.

In comparison to identity, reputation is thus externally oriented (Johnson and Zinkhan, 1990; Balmer and Greyser, 2006; Urde and Greyser, 2015) and based on a firm's past (heritagebased) activities (Aaker, 2004; Urde and Greyser, 2015). Furthermore, reputation represents the firm's critical strategic intangible asset (Fombrun and Van Riel, 2003), exerting an influence on its relationships, performance, behavior, and interactions, especially with its close business partners (cf. Anderson et al., 1994). Based on the reasoning above, we emphasize that a reputation evolves constantly, is emergent, and reconstructed over time. In addition, corporate reputation influences and is influenced by a firm's network connections (Gregory, 1991). As Weiss, Anderson, and MacInnis (1999) illustrate, a reputation can be created and developed based on images and associations that the corporate brand creates in the eyes of other actors, leading towards a general opinion of a company. Reputation is, however, sensitive in nature and can be abruptly changed or even destroyed overnight through critical events like disclosed and rapidly disseminated business scandals, e.g., Volkswagen's falsified $\mathrm{CO}_{2}$ emissions, Toshiba's accounting scandal, and Shkreli's scandal in the drug industry. These types of business scandals result in direct damage of a focal firm's reputation but also exerting an indirect influence on their partners' reputation as well.

Along with this process, business actors interact directly and indirectly with each other, where the internal and external branding dimensions are jointly constructed through mutual INB dimension (see Figure 1 and Figure 2). These issues are presented and discussed in the following sections.

\subsubsection{The mutual INB dimension}

As recent research argues, corporate brand studies need to acknowledge the importance and interrelated nature of internal actors in connection with their external business partners (see, e.g., Urde, 2016; Wider et al., 2018; Koporcic and Halinen, 2018). This is a result of a considerable discussion that has been devoted over the years to corporate branding and the interrelations between its internal and external dimensions. However, previous studies have mostly focused on differences between identity and reputation and their causal relatedness, while trying to find appropriate ways to analyze them (see Hatch and Schultz, 2001; Schultz and de Chernatony, 2002; Ind, 1997). The notion of mutually influential identity and reputation, as a relational 'in-between space', which denotes both internal and external activities, has been rarely acknowledged or studied in business markets (for notable exceptions see Koporcic, 2017; Koporcic and Halinen, 2018).

We note further that companies in business markets are interdependently related due to their close business collaborations and shared interests (Anderson et al., 1994; Håkansson and Snehota, 1995). This interdependency and interactions between partners offer a deeper understanding of INB and add to conceptual knowledge of branding strategies (Ballantyne 
and Aitken, 2007). As a consequence, the corporate brand of each company is influencing and being influenced by other connected actors. This is done through interactive processes, which forms the essence of INB. As such, INB is a matter of shared interest in building and developing mutually related activities, including branding, through several close business relationships. These relationships are created, maintained, and strengthened through managerial and corporate interactions. As Munksgaard and Ford (2017, p. 343) highlight: "Part of the ability to converge self and counterpart interests over time are the social skills of the business manager and its ability to show and create commitment and trust with others." Since human actors are representing their firms while interacting with others, those social interactions are influencing the creation of corporate brands.

Brands that are results of social interactions have been acknowledged in previous literature, highlighting their meaning "in the minds and hearts of people" (Urde, 2016, p. 32). This refers to perceptions that are created in the minds of people, giving corporate brands a human element. This human notion is thus not only concerned with internal and external branding dimensions, where identity and reputation are being created. Instead, we argue that human actors represent an in-between - shared - branding space through which mutual INB dimension comes to being (see Figure 1). Through mutual INB dimension, both socially constructed value components of interactive relationships and corporate branding are brought into play. Based on this reasoning, we are proposing an extended network perspective on corporate branding in business marketing, containing internal, external, and mutual INB dimensions, which are set in motion through managerial interaction.

Figure 1. The main constituents of three Interactive Network Branding dimensions

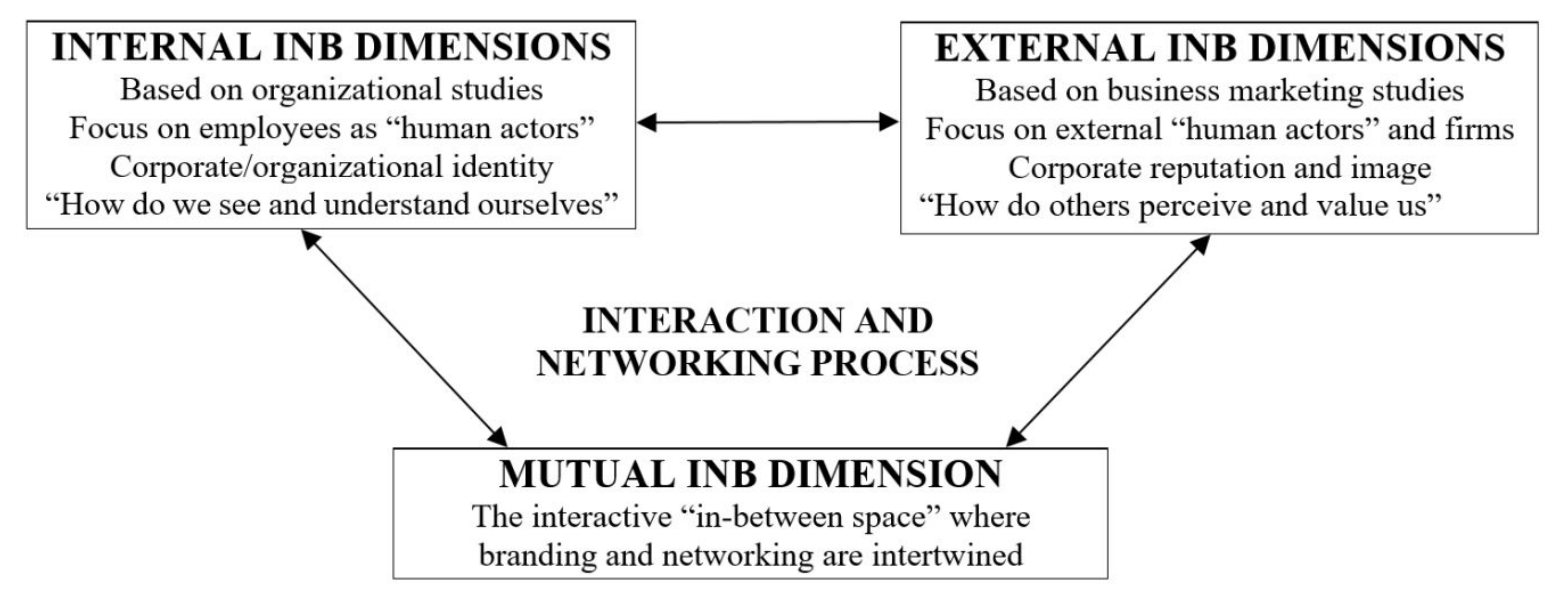

3.2. A conceptual model of Interactive Network Branding

As noted, INB presents a joint activity of actors in a business network, i.e., in settings in which the positions and roles of connected firms emerge and change over time. In other words, INB comes into play through the specific position(s) and role(s) that business actors, through their representatives, play in mutual value-exchange with their networking parties.

Reputation (perceptions held by external actors) and identity (perceptions held by internal 
actors) are presenting two key starting points of the proposed INB model (see Figure 2). By adding a mutual INB dimension, the problem of two 'more isolated' branding aspects is avoided. This mutual aspect denotes a shared 'in-between' understanding concerning the interaction between identity and reputation, thus creating the base of the INB process. In this manner, INB develops a more comprehensive representation of the corporate branding aspects involved in a business network context.

Thus, firms' positions and roles are residing, according to an INB perspective, in the mutual INB dimension (see Figure 2). In other words, in the mutual INB dimension, a strategic network perspective of INB can be found, in which the positions and roles of firms are created and maintained. By adding this dimension, we develop a network perspective to corporate branding research. In this manner, companies are acting in their strategic roles while aiming to create desired positions. As a result, the process of INB is emerging and developing over time in its network context.

Figure 2. A model of Interactive Network Branding

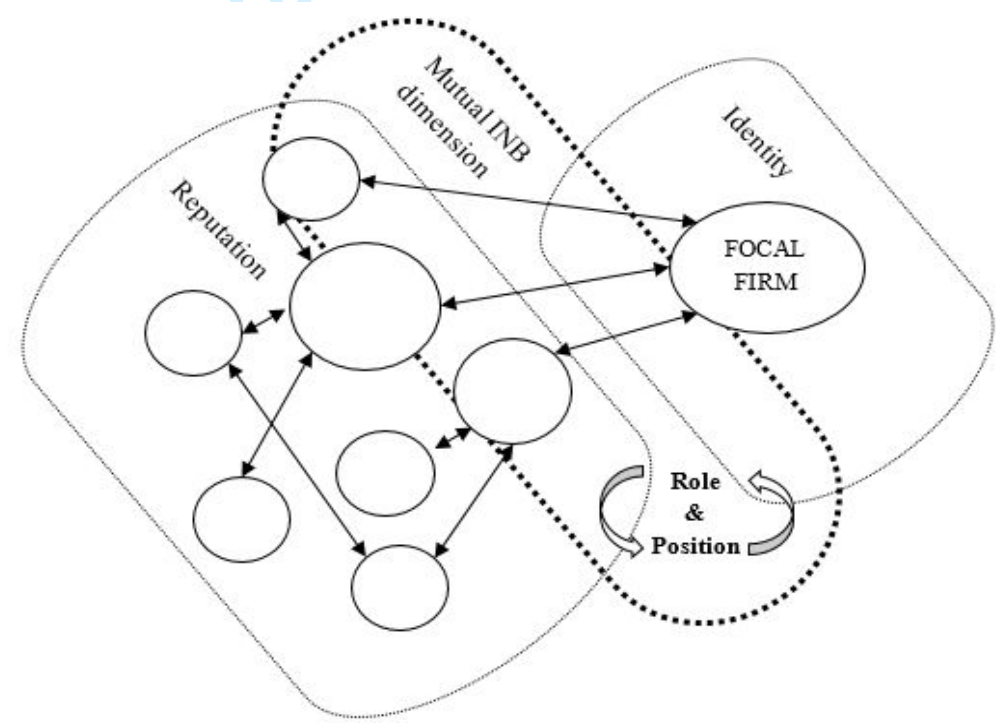

While creating and maintaining their roles and network positions, firms' business partners (external actors) are involved in internal branding processes. In other words, interactions between business partners are influencing both internal and external INB dimensions (Koporcic and Halinen, 2018), by influencing each other's perceptions (Gioia et al., 2010), as well as actions (Mäläskä et al., 2011). INB can, in this manner, be seen as a process that influences the creation of specific network positions and roles of actors in their embedded network relations, through the interplay of the three key INB dimensions. Also, it is essential to note that both previous and existing network roles and positions have a bearing on how future roles and positions will be enhanced through INB processes.

This model, therefore, proposes that mutually connected relationships through INB affect the evolving and changing roles and positions of interdependent business actors. How well firms act in their roles and in creating a position in the network forms the essence of their corporate brand. Interactions taking place in the so-called 'in-between space' are affecting the reputation, identity, and mutual branding activities of connected firms. Actors in their roles 
and positions, thus jointly influence the dynamics of business networks (Abrahamsen et al., 2012).

\section{Conclusions and discussion}

\subsection{Conceptual and methodological implications}

The focus on the business network approach and relevant insights from branding research provide an excellent opportunity for cross-fertilization of ideas between two disciplines. As a result, we have proposed a new conceptual model of Interactive Network Branding (INB). This model elaborates further on the ideas initially proposed by Koporcic and Törnroos (2015) and Koporcic and Halinen (2018), focusing primarily on how it influences firms' creation and development of roles and positions in business networks. In addition, the model provides an extension of brand strategies based on an interactive networking model (Ballantyne and Aitken, 2007). Most of the previous corporate brand research has focused on either corporate identity (e.g., Simões et al., 2005; Purchase et al., 2015), or reputation (e.g., Brown et al., 2010; Walker, 2010; Weis et al., 1999), sometimes even ignoring the importance of one or the other. Thus, in this paper, we have explicitly addressed a need to add a mutual INB dimension, as a critical issue and perspective of the business network. By pinpointing the interactive and collaborative positions and roles between firms in business markets, we offer a new conceptual angle to corporate branding, as well as to business network research.

By acknowledging the interrelated nature of internal and external business actors, we have contributed to the current gaps in the extant corporate branding literature. First, the conceptualization suggests that a corporate brand should be understood as a temporal value outcome of interaction processes and relational investments. Second, corporate branding studied through a focal company (internally) should also be studied externally, through closely connected companies in the network where a firm is embedded. Third, INB should be treated as a strategic concept that companies employ to create network roles and positions in business network settings. These processes can be scrutinized by acknowledging that firms constantly alter their corporate identities to acquire a stronger reputation through interactions with existing and potential business partners. INB thus extends the single firm perspective to include both single-firm and multiple-firm branding processes in B2B markets. This, in turn, produces a mutual and relational branding effect through the connected and interdependent business relationships (see Figures 1 and 2).

The INB conceptual framework is built on the actor-network constellations of branding, by offering a relevant starting point for new and complementary views on corporate branding research (see, e.g., calls from Schultz and Hatch, 2005; Mäläskä et al., 2011; Gyrd-Jones et al., 2013). As a result, INB offers a comprehensive conceptual framework for conducting empirical research. However, it is essential to be aware of the fact that addressing corporate branding as a multi-disciplinary field of research can create obstacles in dealing with diverse 
research fields and perspectives, as well as methods. As we have reviewed both business marketing and organizational theory on corporate branding in order to develop INB, we identified gaps that could generate limitations for future empirical research. These limitations might materialize from a strong but divergent research focus and traditions within the two research fields. Business marketing research is often based on empirical data, while the organizational theory is mostly grounded on conceptual frameworks and perspectives (Hambrick, 2004). Therefore, future research needs to develop appropriate methods to capture INB in empirical settings. We believe some of these current caveats can be overcome by using the network approach with its interactive and dynamic views in corporate branding research.

Concerning methodological approaches and research methods, we propose, for instance, process research (Garud and Van de Ven, 2002; Pettigrew, 1997; Halinen et al., 2012), sensemaking approaches (Weick, 1995), and narrative research (Makkonen et al., 2012; Polkinghorne, 1995), as well as, e.g., historical reconstructions, or ethnographic and action research. Combining longitudinal data with reconstructive historical methods could provide answers on how business relationships and network connections can influence a firm's position and role(s) in embedded networks. In addition, longitudinal case studies could provide in-depth data for gaining an understanding of interpersonal interactions, both internally in firms and externally in business networks (Vallaster and Lindgreen, 2011; Mäläskä et al., 2011; Koporcic and Halinen, 2018). Research within the proposed qualitative domain could be supplemented later with experimental and quantitative methods.

\subsection{Managerial implications \\ "Since a brand is reflected in everything the company does, a holistic branding approach requires a strategic perspective... Building, championing, supporting and protecting strong brands is everyone's job, starting with the CEO."2}

Building on the quote above, we argue that the core of INB is built of individual managers and other firm representatives, as social actors in companies, who comprehend, understand, and represent firms in their roles and network positions. Those individuals play a crucial role in performing INB. And although INB is a combination of both strategically planned and organically co-created branding and networking processes, we focus this paper as well as its managerial implication on the strategic and purposefully oriented part.

Thus, when developing strategic actions and plans through INB, it is essential to define and enact the role that a company plays in a network, in conjunction with its position. The successful alignment of roles and positions over time will create positive perceptions of the company in the mindsets of its business counterparts. In other words, INB will positively influence the unfolding creation of corporate identity and reputation in the firm's network setting. However, we should not neglect the power of a negative reputation that comes as a

\footnotetext{
2 Taken from: (2007) "Executive summary and implications for managers and executives", Journal of Business and Industrial Marketing, Vol. 22 Issue: 6, https://doi.org/10.1108/jbim.2007.08022faf.001
} 
result of discrepancies between how firms represent themselves and what they actually are as business partners. Alternatively, a negative reputation can also reside from a misalignment of roles and positions of a company's business partners. Thus, managers need to be aware that all of the existing, but also new business partners are not only sources of raw materials and services (for suppliers) or of a profit (for buyers), but also acting partners in Interactive Network Branding.

From an INB perspective, corporate identity materializes when the interacting manager(s) communicate their company to potential others, in their web of business partners and other relevant organizations. This representational and dialogical role of an actor has a bearing on corporate reputation creation, which in turn also affects how other actors evaluate the firm. A similar notion is highlighted by Jalkala and Keränen (2014, p. 254): "In industrial markets, personal interaction with customers plays a major role in the actual brand positioning, and every interaction between a firm and its stakeholders becomes an input to brand image [reputation]." Thus, managers have to be particularly cautious regarding their most important network relationships in order to maintain and develop them over time. In addition, mutual interests and objectives of partners, as well as their obligations, need to be aligned jointly for the benefit of the involved parties.

Finally, individuals dealing with brand development and reputation building in business relationships and networks need to understand that they are representing their firm through every action and interaction. Besides interacting with individuals within their own firms, INB is built through direct and indirect interactions with managers and employees from other companies. These boundary-spanning interactions are crucial for the INB processes to materialize (see more on boundary spanning interactions in Koporcic and Halinen, 2018).

\section{References}

Aaker, D.A. (1991), Managing brand equity: Capitalizing on the value of a brand name, The Free Press, New York.

Aaker, D.A. (1996), Building strong brands, The Free Press, New York.

Aaker, D.A. (2004), Brand portfolio strategy, The Free Press, New York.

Aaker, D.A. and Joachimsthaler, E. (2000), Brand leadership, The Free Press, London.

Abrahamsen, M.H., Henneberg, S.C. and Naudé, P. (2012), “Using actors' perceptions of network roles and positions to understand network dynamics", Industrial Marketing Management, Vol. 41 No. 2, pp. 259-269.

Abratt, R. and Kleyn, N. (2012), "Corporate identity, corporate branding and corporate reputations”, European Journal of Marketing, Vol. 46 No. 7/8, pp. 1048-1063.

Albert, S., Ashforth, B. and Dutton, J. (2000), "Organizational identity and identification: Charting new waters and building new bridges", Academy of Management Review, Vol. 25 No. 1, pp. 13-17. 
Anderson, J. C., Håkansson, H. and Johanson, J. (1994), "Dyadic business relationships within a business network context", Journal of Marketing, Vol. 58, pp. 1-15.

Anderson, H., Havila, V., Andersen, P. and Halinen, A. (1998), "Position and roleconceptualizing dynamics in business networks", Scandinavian Journal of Management, Vol. 3, pp. 167-186.

Ballantyne, D. and Aitken R. (2007), "Branding in B2B markets: Insights from the servicedominant logic of marketing", Journal of Business and Industrial Marketing, Vol. 22 No. 6, pp. 363-371.

Balmer, J.M.T. and Gray, E.R. (2003), “Corporate brands: What are they? What of them?", European Journal of Marketing, Vol. 37 No. 7/8, pp. 972-997.

Balmer, J.M.T. and Greyser, S.A. (2006), "Corporate marketing: Integrating corporate identity, corporate branding, corporate communications, corporate image and corporate reputation", European Journal of Marketing, Vol. 40 No. 7/8, pp. 730 741.

Balmer, J.M. (2017), “Advances in corporate brand, corporate heritage, corporate identity and corporate marketing scholarship”, European Journal of Marketing, Vol. 51 No. 9/10, pp. 1462-1471.

Bengtsson, A. and Servais, P. (2005), "Co-branding in industrial markets", Industrial Marketing Management, Vol. 34, pp. 706-713.

Biraghi, S. and Gambetti, R.C. (2015), "Corporate branding: where are we? A systematic communication-based inquiry", Journal of Marketing Communications, Vol. 21 No. 4, pp. 260-283.

Brennan, R. and Turnbull, P.W. (2002), "Sophistry, relevance and technology transfer in management research: an IMP perspective", Journal of Business Research, Vol. 55 No. 7, pp. 595-602.

Brown, T.J., Dacin, P.A., Pratt, M.G. and Whetten, D.A. (2006), "Identity, intended image, construed image, and reputation: An interdisciplinary framework and suggested terminology", Journal of the academy of marketing science, Vol. 34 No. 2, pp. 99106.

Brown, T.J., Dacin, P.A. and Pitt, L.F. (2010), "Corporate image and reputation in B2B markets: Insights from CI/ARG 2008", Industrial Marketing Management, Vol. 39, pp. 709-711.

de Chernatony, L. and Cottam, S. (2008), "Interactions between organisational cultures and corporate brands", Journal of Product and Brand Management, Vol. 17 No. 1, pp. $13-24$.

de Chernatony, L. and Harris, F. (2000), "Developing corporate brands through considering internal and external stakeholders", Corporate Reputation Review, Vol. 3 No. 3, pp. 268-274.

Davies, G., Chun, R., da Silva, V. and Roper, S. (2003), Corporate reputation and competitiveness, Routledge, London. 
Dutton, J. E., Dukerich, J. M. and Harquail, C. V. (1994), "Organizational images and member identification”, Administrative Science Quarterly, Vol. 39, pp. 239-263.

Fetscherin, M. and Usunier, J.C. (2012), "Corporate branding: An interdisciplinary literature review”, European Journal of Marketing, Vol. 46 No. 5, pp. 733-753.

Fombrun, C.J. and Van Riel, C.B.M. (2003), Fame and Fortune: How successful companies build winning reputations. Upper Saddle River, NJ: FT Prentice Hall.

Ford, D. (2004), “The IMP group and international marketing. Guest editorial”, International Marketing Review, Vol. 21 No. 2, pp. 139-41.

Garud, R. and Van de Ven, A. H. (2002), Strategic change processes. In A. Pettigrew, H. Thomas, and R. Whittington (Eds). Handbook of Strategy and Management (pp. 206-231). London: Sage.

Gioia, D.A., Schultz, M. and Corley, K.G. (2000), “Organizational Identity, Image, and Adaptive Instability", Academy of Management Review, Vol. 25, pp. 63-81.

Gioia, D. A., Price, K. N., Hamilton, A. L. and Thomas, J. B. (2010), "Forging an identity: An insider-outsider study of processes involved in the formation of organizational identity", Administrative science quarterly, Vol. 55 No. 1, pp. 1-46.

Gotsi, M. and Wilson, A.M. (2001), "Corporate reputation: seeking a definition”, Corporate Communications: An International Journal, Vol. 6 No. 1, pp. 24-30.

Gregory, J. R. (1991), Marketing corporate image, NTC Business Books: Chicago.

Gyrd-Jones, R., Merrilees, B. and Miller, D. (2013), "Revisiting the complexities of corporate branding: Issues, paradoxes, solutions", Journal of Brand Management, Vol. 20 No. 7, pp. 571-589.

Halinen, A., Medlin, C.J. and Törnroos, J.Å. (2012), "Time and process in business network research", Industrial Marketing Management, Vol. 41 No. 2, pp. 215-223.

Hambrick, D.C. (2004), "The disintegration of strategic management: It's time to consolidate our gains", Strategic Organization, Vol. 2, pp. 91-98.

Harris, F. and de Chernatony, L. (2001), "Corporate branding and corporate brand performance", European Journal of Marketing, Vol. 35 No. 3/4, pp. 441-456.

Hatch, M.J. and Schultz, M. (1997), "Relations between organizational culture, identity and image", European Journal of Marketing, Vol. 31 No. 5/6, pp. 356-365.

Hatch, M.J. and Schultz, M. (2001), "Are the strategic stars aligned for your corporate brand?", Harvard Business Review, Vol. 79 No. 2, pp. 128-134.

Hatch, M.J. and Schultz, M. (2009), "Of bricks and brands: From corporate to enterprise branding", Organizational Dynamics, Vol. 38 No. 2, pp. 117-130.

Herbst, U., Schmidt, N., Ploder, S. and Austen, V. (2012), "What do we know about B2B branding in marketing research? A comprehensive status quo analysis", Competitive paper published at the $28^{\text {th }}$ IMP-conference in Rome, Italy.

Håkansson, H. (1982), International marketing and purchasing of industrial goods: An 
interaction approach, Wiley, London.

Håkansson, H. (ed.) (1987), Industrial technological development: A network approach, Croom Helm, London.

Håkansson, H., Ford, D., Gadde, L. E., Snehota, I. and Waluszewski, A. (2009), Business in networks, John Wiley and Sons, Chichester.

Håkansson, H. and Snehota, I. (1995), Developing relationships in business networks, Routledge, London.

Ind, N. (1997), The corporate brand, Macmillan Business, Basingstoke.

Jalkala, A. M. and Keränen J. (2014), "Brand positioning strategies for industrial firms providing customer solutions", Journal of Business and Industrial Marketing, Vol. 29 No. 3, pp. 253-264.

Jalkala, A. and Saminen R. T. (2010), "Practices and functions of customer reference marketing - Leveraging customer references as marketing assets", Industrial Marketing Management, Vol. 39 No. 6, pp. 975-985.

Johanson, J. and Mattsson, L. G. (1992), Network positions and strategic action - An analytical framework. In B. Axelsson, and G. Easton (Eds.), Industrial Networks - a new view of reality (pp. 205-217), Routledge, London.

Johnson, M. and Zinkhan, G. M. (1990), "Defining and measuring company image", Proceedings of the 13th Annual Conference of the Academy of Marketing Science, Vol. 13, pp. 346-50.

Kalafatis, S. P., Remizova, N., Riley, D. and Singh, J. (2012), "The differential impact of brand equity on B2B co-branding", Journal of Business and Industrial Marketing, Vol. 27 No. 8, pp. 623-634.

Kantanen, H. (2012), "Identity, image and stakeholder dialogue", Corporate Communications: An International Journal, Vol. 17 No. 1, pp. 56-72.

King, S. (1991), "Brand building in the 1990s", Journal of Consumer Marketing, Vol. 8 No. 4, pp. 43-52.

Knox, S. and Bickerton, D. (2003), "The six conventions of corporate branding”, European Journal of Marketing, Vol. 37 No. 7/8, pp. 998-1016.

Koporcic, N. and Törnroos, J. (2015), "Developing interactive branding in business networks", In The 31st IMP Conference (pp. 1-18).

Koporcic, N. (2017), Developing Interactive Network Branding in Business Markets: Case studies of SMEs from Developed and Emerging Business Markets. Ph.D. dissertation, Åbo Akademi University, Turku.

Koporcic, N. and Halinen, A. (2018), "Interactive Network Branding: Creating corporate identity and reputation through interpersonal interaction", IMP Journal, Vol. 12 No. 2, pp. 392-408.

Koporcic, N., Ivanova-Gongne, M., Nyström, A.G. and Törnroos, J.Å. (Eds.). (2018), Developing Insights on Branding in the B2B Context: Case Studies from Business 
Practice. Emerald Publishing Limited.

Makkonen, H., Aarikka - Stenroos, L. and Olkkonen, R. (2012), "Narrative Approach in Business Network Process Research - Implications for Theory and Methodology", Industrial Marketing Management, Vol. 41 No. 2, pp. 287-299.

Mäläskä, M., Saraniemi, S. and Tähtinen, J. (2011), "Network actors' participation in B2B SME branding", Industrial Marketing Management, Vol. 40 No. 7, pp. 1144-1152.

Medlin, C. and Törnroos, J.-Å. (2007), "Inter-firm interaction from a human perspective", Finanza Marketing e Produzione, Vol. 25 No. 1, pp. 43-58.

Medlin, C. and Törnroos, J.-A. (2009), "Inter-firm interaction: The human role in change and stability", Proceedings of the IMP Conference 2009, held in Kuala Lumpur Malaysia, P. Batt (ed.)

Melewar, T. C., Gotsi, M. and Andriopoulos, C. (2012), "Shaping the research agenda for corporate branding: avenues for future research", European Journal of Marketing, Vol. 46 No. 5, pp. 600-608.

Morgan, F., Deeter-Schmelz, D. and Moberg, C. R. (2007), "Branding implications of partner firm-focal firm relationships in business-to-business service networks", Journal of Business and Industrial Marketing, Vol. 22 No. 6, pp. 372-382.

Morhart, F., Herzog, W. and Tomczak, T. (2009), "Brand-specific leadership: turning employees into brand champions", Journal of Marketing, Vol. 73, pp. 122-142.

Mudambi, S., Doyle, P. and Wong, V. (1997), “An exploration of branding in industrial markets”, Industrial Marketing Management, Vol. 26, pp. 433-446.

Mudambi, S. (2002), "Branding importance in business-to-business markets. Three buyer clusters", Industrial Marketing Management, Vol. 31, pp. 525-533.

Mukherjee, A. and Balmer, J.M.T. (2008), "New frontiers and perspectives to corporate brand management: In search of a theory", International Studies of Management and Organization, Vol. 34 No. 4, pp. 3-19.

Munksgaard, K.B. and Ford, D. (2017), "The business actor and business management", IMP Journal, Vol. 11 No. 2, pp. 327-347.

Möller, K.E. (2013), "Relationships and Networks". In Baker, M. J. and M. Saren (Eds.). Marketing Theory - A student text. London and New York: Sage, 387-414.

Pettigrew, A.M. (1997), "What is a Processual Analysis?", Scandinavian Journal of Management, Vol. 13 No. 4, pp. 337-348.

Polkinghorne, D. E. (1995), Narrative configuration in qualitative analysis, In J. A. Hatch and R. Wisniewski (Eds.). Life history and narrative (pp. 5-23), Falmer Press, London.

Purchase, S., Da Silva Rosa, R. and Schepis, D. (2015), "Identity construction through role and network position”, Industrial Marketing Management, Vol. 54, pp. 154-163.

Roper, S. and Davies, G. (2007), “The corporate brand: Dealing with multiple stakeholders”, Journal of Marketing Management, Vol. 23 No. 1, pp. 75-90. 
Schultz, M. and de Chernatony, L. (2002), "Introduction: the challenges of corporate branding", Corporate Reputation Review, Vol. 5 No. 2-3, pp. 105-114.

Schultz, M. and Hatch, M. J. (2003), "The cycles of corporate branding: Case of the LEGO Company”, California Management Review, Vol. 46 No. 1, pp. 6-26.

Schultz, M. and Hatch, M. J. (2005), "Building theory from practice", Strategic Organization, Vol. 3 No. 3, pp. 337-348.

Schultz, M. and Hatch, M.J. (2007), "Third wave branding: Breaking the ice", Communication Director, Vol. 4, pp. 58-62.

Scott, S.G. and Lane, V.R. (2000), "A stakeholder approach to organizational identity", Academy of Management review, Vol. 25 No. 1, pp. 43-62.

Seyedghorban, Z., Matanda, M.J. and LaPlaca, P. (2016), “Advancing theory and knowledge in the business-to-business branding literature", Journal of Business Research, Vol. 69 No. 8, pp. 2664-2677.

Simões, C, Dibb, S. and Fisk, R.P. (2005), "Managing corporate identity: An internal perspective", Academy of Marketing Science Journal, Vol. 33 No. 2, pp. 153-168.

Turnbull, P., Ford, D. and Cunningham, M. (1996), "Interaction, relationships and networks in business markets: an evolving perspective", Journal of Business and Industrial Marketing, Vol. 11 No. 3/4, pp. 44-62.

Törmälä, M. and Gyrd-Jones, R.I. (2017), "Development of new B2B venture corporate brand identity: A narrative performance approach", Industrial Marketing Management, Vol. 65, pp. 76-85.

Urde, M. and Greyser, S.A. (2015), "The Nobel prize: The identity of a corporate heritage brand", Journal of Product and Brand Management, Vol. 24 No. 4, pp. 318-332.

Urde, M. (2016), “The brand core and its management over time", Journal of Product and Brand Management, Vol. 25 No. 1, pp. 26-42.

Vallaster, C. and de Chernatony, L. (2006), "Internal brand building and structuration: the role of leadership", European Journal of Marketing, Vol. 40 No. 7/8, pp. 761-784.

Vallaster, C. and Lindgreen, A. (2011), "Corporate brand strategy formation: brand actors and the situational context for a business-to-business brand", Industrial Marketing Management, Vol. 40 No. 7, pp. 1133-1143.

Walker, K. (2010), "A systematic review of the corporate reputation literature: definition, measurement, and theory", Corporate Reputation Review, Vol. 12 No. 4, pp. 357-87.

Webster, F.E. and Keller, K.L. (2004), “A roadmap for branding in industrial markets”, Brand Management, Vol. 11 No. 5, pp. 388-402.

Weick, K. (1995), Sensemaking in Organizations, Sage, London.

Weiss, A., Anderson, E. and MacInnis, D.J. (1999), "Reputation management as a motivation for sales structure decisions", Journal of Marketing, Vol. 63, pp. 74-89.

Wider, S., von Wallpach, S. and Mühlbacher, H. (2018), "Brand management: Unveiling the 
delusion of control", European Management Journal, Vol. 36 No. 3, pp. 301-305. 